GRASAS Y ACEITES 66 (4)

October-December 2015, e096

ISSN-L: 0017-3495

doi: http://dx.doi.org/10.3989/gya.0109151

\title{
Minor components of pomace olive oil enhance VLDL-receptor expression in macrophages when treated with postprandial triglyceride-rich lipoproteins
}

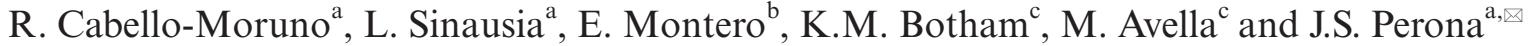 \\ ${ }^{a}$ Nutrition and Lipid Metabolism. Instituto de la Grasa (CSIC). Edif. 46 Campus Universidad Pablo de Olavide. 41013. Seville. Spain \\ ${ }^{b}$ Emergencies Services. General Hospital. HHUU Virgen del Rocío. Av. Manuel Siurot s/n. 41013. Seville. Spain \\ ${ }^{c}$ Department of Comparative Biomedical Sciences, The Royal Veterinary College, Royal College St, London, NW1 0TU, UK \\ ${ }^{\sharp}$ Corresponding author: perona@ig.csic.es
}

Submitted: 15 January 2015; Accepted: 01 April 2015

SUMMARY: Pomace olive oil (POO) is rich in minor components, which can modulate the composition of postprandial triglyceride-rich lipoproteins (TRL) and their uptake by macrophages. The aim of the present study was to investigate the effects of postprandial TRL obtained after the ingestion of meals containing POO or refined olive oil (ROO) on foam cell formation, one of the initial steps of atherogenesis. Meals were administered to 9 healthy men and TRL were isolated from serum $4 \mathrm{~h}$ after the intake. POO intake led to TRL with lower triglyceride/apo B48 and triglyceride/apo B100 ratios compared to ROO. Upon incubation of THP-1 macrophages with the TRL, an increase in the intracellular triglyceride content and foam cell formation was observed. Compared to ROO-TRL, the only receptor involved in lipoprotein uptake that showed changes in the mRNA expression after treatment with POO-TRL was the VLDL-receptor (VLDLr). In conclusion, the intake of POO modified the composition of human TRL, which increased the VLDLr gene expression in macrophages. However, the changes were not sufficient to enhance foam cell formation.

KEYWORDS: Macrophages; Pomace olive oil; Postprandial; Triglycerides; VLDL-receptor

RESUMEN: Los componentes menores del aceite de oliva de orujo aumentan la expresión del receptor VLDL en macrófagos tratados con lipoproteínas ricas en triglicéridos postprandiales. El aceite de orujo de oliva (AOO) es rico en componentes menores que pueden modular la composición de lipoproteínas ricas en triglicéridos postprandiales (TRL) y su captación por macrófagos. El objetivo del presente estudio fue investigar los efectos de TRL obtenidas después de la ingesta de comidas que contenían AOO o aceite de oliva refinado (AOR) sobre la formación de células espumosas, uno de los pasos iniciales de la aterogénesis. Las comidas fueron administradas a 9 hombres sanos y las TRL fueron aisladas del suero sanguíneo $4 \mathrm{~h}$ después de la ingesta. La ingesta de AOO dio lugar a TRL con menor ratio triglicéridos/apo B48 y triglicéridos/apo B100 en comparación con AOR. Tras la incubación de macrófagos THP-1 con las TRL, se observó un aumento en el contenido de triglicéridos intracelular y la formación de células espumosas. En comparación con TRL-AOR, el único receptor implicado en la captación de lipoproteínas que mostró cambios en la expresión génica después del tratamiento con TRL-AOO fue el receptor VLDL (VLDLr). En conclusión, la ingesta de AOR modificó la composición de TRL humanas, lo que aumentó la expresión de VLDLr en macrófagos, aunque los cambios no fueron suficientes para mejorar la formación de células espumosas.

PALABRAS CLAVE: Aceite de orujo de oliva; Macrófagos; Postprandial; Receptor VLDL; Triglicéridos

Citation/Cómo citar este artículo: Cabello-Moruno R, Sinausia L, Montero E, Botham KM, Avella M, Perona JS. 2015. Minor components of pomace olive oil enhance VLDL-receptor expression in macrophages when treated with postprandial triglyceride-rich lipoproteins. Grasas Aceites 66 (4): e096. doi: http://dx.doi.org/10.3989/gya.0109151.

Copyright: (C) 2015 CSIC. This is an open-access article distributed under the terms of the Creative Commons Attribution-Non Commercial (by-nc) Spain 3.0 Licence. 


\section{INTRODUCTION}

It has become clear in the last years that postprandial lipemia, which is caused by raised levels of triglyceride-rich lipoproteins (TRL) present in the blood after a meal containing fat, may be a risk factor for atherosclerosis (Jackson et al., 2012). According to the European Atherosclerosis Society Consensus Panel the association between triglycerides (TG) and cardiovascular disease (CVD) is potentially driven by the number of TRL (Chapman et al., 2011). Circulating TRL include chylomicrons (CM), VLDL and their remnants. During the postprandial phase, TG are carried in the circulation by $\mathrm{CM}$, which are synthesized in the intestine and transport fat of dietary origin (exogenous fat), and VLDL, which are synthesized and secreted by the liver (endogenous fat) (Jackson et al., 2012). TRL can cross the endothelial barrier and enter into the vascular wall (Mamo and Wheeler, 1994), where they can interact with lipoprotein receptors on macrophages, enhancing lipid accumulation and leading to foam cell formation (Napolitano et al., 2003).

The magnitude and duration of the postprandial TG response is influenced by a number of metabolic processes, including the rate of TG secretion from the intestine and the liver, the activity of enzymes involved in the TRL processing and the rate of clearance of TRL remnants by receptormediated pathways (Jackson et al., 2012). The type of dietary lipids carried in TRL is crucial in these processes. Diets enriched in MUFA are associated with a low rate of cardiovascular mortality and it has been demonstrated that different MUFA-rich oils produce different effects on the magnitude and duration of postprandial triglyceridemia (Abia et al., 2001). Despite the multiple advantages attributed to MUFA, an increasing number of studies point out that the content of beneficial fatty acids alone cannot fully explain the impact of MUFA-rich oils on health and that minor components can exert an important role (Perona et al., 2006). Minor lipid components from dietary fats are absorbed in the intestine similarly to other lipids and they are incorporated into postprandial TRL for their transport in plasma. Once delivered to the tissues as part of TRL they may have important physiological effects (Perona et al., 2008).

In previous studies, $\mathrm{CM}$ remnants have been shown to induce extensive lipid accumulation in a variety of macrophage types, including those derived from the human monocyte cell line THP-1 (Moore et al., 2005). The exact mechanisms by which TRL are taken up by macrophages are not yet clearly defined. However, there are several membrane receptors identified as possible candidates that appear to be involved in this process (Elsegood et al., 2001). In the present study, we investigated the effects of postprandial TRL obtained after the ingestion of pomace olive oil (POO) and refined olive oil (ROO) on lipid accumulation and foam cell formation in THP-1 macrophages. The composition of both oils is similar with regard to fatty acids but they differ in minor components of the unsaponifiable fraction. POO is obtained from the solid phase resulting after mechanical extraction of virgin olive oil (VOO), and is rich in unsaponifiable compounds but lacks phenolics. TRL obtained after the intake of POO and ROO present differences in their content of minor components (Cabello-Moruno et al., 2014) and it is possible, therefore, that this may affect their uptake by macrophages and their promotion of foam cell formation. We also aimed to determine the contribution of apolipoprotein (apo) E-dependent (LDLr, LRP, VLDLr) and scavenger (SR-A2, SR-B1 and CD36) receptors to the removal of apoE-containing native TRL by macrophages. We have previously shown that TRL particles isolated at $4 \mathrm{~h}$ after the oil intake is the time point at which the maximum cellular incorporation of TG is found (Cabello-Moruno et al., 2014). Therefore, we investigated the effects of postprandial TRL obtained $4 \mathrm{~h}$ after the ingestion of meals containing POO or ROO on foam cell formation by analyzing the intracellular lipid accumulation and gene expression of membrane receptors involved in the process.

\section{MATERIALS AND METHODS}

\subsection{Subjects and Study Design}

Nine healthy men aged $26.2 \pm 4.3$ years with a BMI $23.7 \pm 2.0 \mathrm{~kg} \cdot \mathrm{m}^{-2}$ participated in the study. Subjects were excluded if they suffered from any digestive or metabolic disorder, were taking dietary supplements, or were under medication of any kind. A fasting blood sample was collected to ensure that recruited subjects had plasma TG and glucose concentrations within normal limits (Table 1).

TABLE 1. Baseline data of normo-lipidemic men participating in the study ${ }^{\mathrm{a}}$

\begin{tabular}{lcc}
\hline & $\begin{array}{c}\text { Concentration } \\
\left(\mathbf{m g} \cdot \mathbf{d L} \mathbf{L}^{-1}\right)\end{array}$ & $\begin{array}{c}\text { Reference range } \\
\left(\mathbf{m g} \cdot \mathbf{d L}^{-1}\right)^{\mathbf{b}}\end{array}$ \\
\hline Total Cholesterol & $151.5 \pm 7.3$ & $<200$ \\
LDL-Cholesterol & $97.6 \pm 4.0$ & $<100$ \\
HDL-Cholesterol & $60.7 \pm 6.0$ & $>40$ \\
Triglyceride & $67.5 \pm 5.7$ & $<200$ \\
Apo A & $147.8 \pm 7.7$ & $>120^{\mathrm{c}}$ \\
Apo B & $59.3 \pm 2.3$ & $<90^{\mathrm{c}}$ \\
LDL/HDL & $1.6 \pm 0.1$ & - \\
Apo B/apo A & $0.4 \pm 0.1$ & -
\end{tabular}

${ }^{\mathrm{a}}$ Data are expressed as means \pm SEM, $\mathrm{n}=9$.

${ }^{\mathrm{b}}$ Reference values for men according to the American Heart Association.

${ }^{\mathrm{c}}$ Data for patients with a high cardiovascular risk. 
The experiment was carried out over three weeks, being the second week a wash-out period in which volunteers returned to their normal diet. Participants were given $1 \mathrm{~L}$ of $\mathrm{ROO}$ in the week before the beginning of the study in order to minimize the effect of the habitual dietary oil. On the last day of that week, the subjects consumed a meal that consisted of 1 slice of brown bread (28 g), 1 skim yoghurt (125 g) and plain pasta (100 g, cooked with $200 \mathrm{~mL}$ of water) with tomato sauce $(130 \mathrm{~g})$ previously mixed with POO or ROO (70 g). The oils contributed with 2587 $\mathrm{kJ}$ of energy while the whole meal provided $4523 \mathrm{~kJ}$, distributed as follows: $32.5 \%$ carbohydrate, $7.6 \%$ protein, and $59.9 \%$ fat. POO and ROO were kindly supplied by Oleicola El Tejar, S.A. (El Tejar, Cordoba, Spain). The fatty acid composition of the two oils was similar (Table 2), but there were marked differences in the content of their unsaponifiable fractions, with POO having considerably higher levels of sterols, tocopherols, erythrodiol + uvaol and waxes (Table 3).

TABLE 2. Fatty acid composition of refined (ROO) and pomace (POO) olive oil employed in the study

\begin{tabular}{lcc}
\hline Fatty acid & ROO $\left(\mathbf{g} \cdot \mathbf{1 0 0} \mathbf{g}^{\mathbf{- 1}}\right)$ & POO $\left(\mathbf{g} \cdot \mathbf{1 0 0} \mathbf{g}^{\mathbf{- 1}}\right)$ \\
\hline $16: 0$ & 10.6 & 10.4 \\
18:0 & 3.3 & 2.8 \\
20:0 & 0.8 & 0.9 \\
16:1 (n-7) & 0.8 & 0.9 \\
18:1 (n-9) & 78.7 & 76.2 \\
18:2(n-6) & 5.2 & 7.6 \\
Others & 0.8 & 1.0 \\
\hline
\end{tabular}

TABLE 3. Unsaponifiable fraction composition of refined (ROO) and pomace (POO) olive oils employed in the study

\begin{tabular}{lcc}
\hline & ROO $\left(\mathbf{m g} \cdot \mathbf{k g}^{\mathbf{- 1}}\right.$ ) & POO $\left(\mathbf{m g} \cdot \mathbf{k g} \mathbf{~}^{\mathbf{1}}\right.$ ) \\
\hline Unsaponifiable fraction (\%) & 1.3 & 1.6 \\
Sterols & 1120.0 & 2245.0 \\
Cholesterol (\%) & 0.3 & 0.3 \\
Brasicasterol (\%) & 0.1 & 0.1 \\
Campesterol (\%) & 3.2 & 2.4 \\
Stigmasterol (\%) & 0.9 & 0.9 \\
$\beta$-sitosterol (\%) & 95.5 & 95.2 \\
$\Delta$ 7-stigmasterol (\%) & 0.2 & 0.3 \\
Tocopherols & 220.5 & 981.2 \\
$\alpha$-tocopherol (\%) & 94.4 & 80.7 \\
$\beta$-tocopherol (\%) & 4.1 & 8.9 \\
-tocopherol (\%) & 1.5 & 10.4 \\
Squalene & 2642.0 & 2543.0 \\
Erythrodiol+uvaol & 17.0 & 507.0 \\
Waxes & 123.0 & 3484.0 \\
\hline
\end{tabular}

Participants were asked to have a low-fat dinner the evening prior to the postprandial study and to abstain from alcohol drinking and smoking for $24 \mathrm{~h}$. On arrival, after an overnight fast (12 h), a cubital vein was catheterized and a baseline blood sample was taken immediately before consumption of the test meal. Four hours after the intake blood samples were collected. The postprandial time point for TRL isolation was chosen according to the hour at which the maximum TRL incorporation into cells had been observed previously (Cabello-Moruno et al., 2014). During the course of the experiment, subjects were allowed to drink water and to undertake only light activities. Serum was recovered by centrifugation $\left(1620 \times \mathrm{g}, 30 \mathrm{~min}, 4^{\circ} \mathrm{C}\right)$ and sodium azide, phenymehylsulfonyl fluoride and aprotinin (Sigma-Aldrich, Poole, UK) were added to a final concentration of $1 \mathrm{mmol} \cdot \mathrm{L}^{-1}, 10 \mu \mathrm{mol} \cdot \mathrm{L}^{-1}$, and $0.5 \mathrm{mg} \cdot \mathrm{L}^{-1}$, respectively.

\subsection{Postprandial TRL isolation}

Postprandial TRL were isolated from $4.5 \mathrm{~mL}$ of serum collected at $4 \mathrm{~h}$ after the intake of the test meal. Serum was layered under $6 \mathrm{~mL}$ of $\mathrm{NaCl}$ solution $\left(d=1.006 \mathrm{~kg} \cdot \mathrm{L}^{-1}\right)$ and TRL were obtained by a single ultracentrifugation spin $\left(39,000 \mathrm{rpm}, 16 \mathrm{~h}, 12{ }^{\circ} \mathrm{C}\right)$. Ultracentrifugation was performed using a SW41Ti swinging bucket rotor in a Beckman L8-70M preparative ultracentrifuge (Beckman Instruments, Palo Alto, USA). TRL were rapidly frozen at $-80^{\circ} \mathrm{C}$ and thawed just before use. Since severe changes in temperature might cause an alteration in TRL structure, particles were checked for aggregations before use in culture.

\subsection{TRL lipid and apolipoprotein B composition}

TRL obtained from $4.5 \mathrm{~mL}$ of serum (aprox. $1 \mathrm{~mL}$ ) were adjusted to a final volume of $1.5 \mathrm{~mL}$ with a $\mathrm{KCl}$ solution $(0.1 \mathrm{M})$. Total lipids in TRL were extracted following a modification to the method of Folch et al. (1957). The extracted lipids were dissolved in $1 \mathrm{~mL}$ of chloroform:methanol $(2: 1, \mathrm{v} / \mathrm{v})$. Aliquots were made and kept at $-20^{\circ} \mathrm{C}$ until use.

Lipid class composition was determined by HPLC as described by Perona and Ruiz-Gutierrez (2004). In brief, $10 \mathrm{~mL}$ of lipids were dissolved in chloroform-methanol $(2: 1, \mathrm{v} / \mathrm{v})$ and injected by an automatic sampler into a 2690 Alliance liquid chromatograph (Waters, Milford, MA) controlled by the Empower System (Waters, Milford, MA). Detection was accomplished with a model 2420 light-scattering detector (Waters, Milford, MA). The separation of lipid classes was carried out on a Lichrosphere diol column ( $250 \mathrm{~mm}, 4.6 \mathrm{~mm}, 5 \mathrm{~mm}$ particle size; Merck, Darmstadt, Germany) using a gradient-elution system containing hexane, 2-propanol and methanol. Stock solutions of cholesteryl oleate, triolein, cholesterol and phosphatidylcholine were prepared in chloroform-methanol $(2: 1, \mathrm{v} / \mathrm{v})$ and used as standard 
for the identification and quantification of cholesteryl esters (CE), TG, free cholesterol (FC) and phospholipids (PL), respectively. The precision of the method ranged from $2.44 .0 \%$ for lipid standards and $6.8-11.7 \%$ for TRL.

Apo B48 and apo B100 were quantified after separation by SDS-PAGE. Electrophoresis was carried out using the buffer system described by Laemmli (1970). The gels contained a 4-15\% acrylamide gradient, $0.1 \%$ SDS, and $0.375 \mathrm{M}$ Tris. A stacking gel $(5 \%$ acrylamide, $0.1 \%$ SDS, $2 \mathrm{mM}$ EDTA, $0.11 \mathrm{M}$ Tris-HCl, $\mathrm{pH}$ 6.8) was added with a 10-slot well-forming comb. Non-delipidated lipoprotein samples (3 $\mathrm{mg}$ of protein) were reduced in an SDS sample buffer ( $3 \%$ SDS, EDTA $0.8 \mathrm{mM}, 5 \%$ mercaptoethanol, $0.004 \%$ bromophenol blue, $0.05 \mathrm{M}$ Tris- $\mathrm{HCl}, 10 \%$ glycerol, $\mathrm{pH} 6.8$ ) for $3 \mathrm{~min}$ at $100{ }^{\circ} \mathrm{C}$. Gels were run at $60 \mathrm{~V}$ for $3 \mathrm{hr}$. Gels were fixed with a 10\% methanol: $7 \%$ acetic acid solution for $30 \mathrm{~min}$ and stained overnight with SYPRO Ruby Protein Gel Stain (Molecular Probes). De-staining was achieved with a $1 \mathrm{~h}$ wash with the $10 \%$ methanol: $7 \%$ acetic acid solution. The two molecular weight forms of apo B were clearly separated in this gel system and were identified by comparing the distance they migrated into the gels with known molecular weight standards (Sigma Marker, Wide Range (M.W. 6.5$250 \cdot 0 \mathrm{kDa}$ ). The gel was scanned using the Gel Doc 1000 system (Bio-Rad, Richmond, CA) and analyzed with the software Molecular Analyst v.1.6 (Bio-Rad, Richmond, CA). All samples from the same subject were run on the same gel to enable comparison after separation and staining in the same conditions. Considering that apo B-100 and B-48 show the same chromogenicity (Karpe and Hamsten, 1994), the relative amounts of the two isoforms were calculated from the staining intensity, and their absolute masses were calculated from the total apo B mass determined by immunoturbidimetry (Sigma Diagnostics, St. Louis, MO).

\subsection{Culture of THP-1 macrophages}

THP-1 monocytes $(3-9 \times 105$ cells/ml) in RPMI 1640 supplemented with fetal bovine serum $(10 \% \mathrm{v} / \mathrm{v})$, penicillin $\left(100 \mathrm{U} \cdot \mathrm{mL}^{-1}\right)$, streptomycin $\left(100 \mathrm{mg} \cdot \mathrm{mL}^{-1}\right)$ and 2-mercaptoethanol $(20 \mu \mathrm{M})$ were differentiated into macrophages by incubation with phorbol 12-myristate 13-acetate (PMA, $200 \mathrm{ng} \cdot \mathrm{mL}^{-1}$ ) for $72 \mathrm{~h}$ at $37^{\circ} \mathrm{C}$ in $5 \% \mathrm{CO} 2: 95 \%$ air. Confluency of adherent cells was 70-80\% in all experiments and cell viability was $>95 \%$ and was unaffected by incubation with TRL.

\subsection{Oil red $O$ staining}

Cells $\left(3 \times 105\right.$ cells $\left.\cdot \mathrm{mL}^{-1}\right)$ were incubated with TRL $\left(15 \mu \mathrm{g}\right.$ cholesterol $\left.\cdot \mathrm{mL}^{-1}\right)$ for $24 \mathrm{~h}$, washed with PBS and $60 \%$ propan-2-ol, then Oil red $\mathrm{O}(0.5 \%(\mathrm{w} / \mathrm{v})$ in
$40 \%$ propan-2-ol $\left./ \mathrm{H}_{2} \mathrm{O}(\mathrm{v} / \mathrm{v})\right)$ was added. After $15 \mathrm{~min}$, the stain was removed and the cells were washed twice with PBS.

\subsection{Intracellular lipid composition}

The cells $(8 \times 105$ cells $/ \mathrm{ml})$ were incubated with TRL ( $15 \mu \mathrm{g}$ cholesterol $\left.\cdot \mathrm{mL}^{-1}\right)$ for $48 \mathrm{~h}$, after which they were washed with PBS and scraped off the plates with $700 \mathrm{~mL}$ of PBS. The cells were lysed by sonication for 5 seconds (2 cycles) at $50 \mathrm{~W}$ using a Bandelin Sonoplus HD2070 apparatus (Bandelin electronic, Berlin, Germany). An aliquot of $50 \mathrm{ml}$ was used to determine the protein content using the method of Bradford. Lipids were extracted using the method of Folch et al. (1957). TG, FC and CE content were determined by enzymatic analysis using commercial enzymatic reagent kits (Alpha Laboratories, Eastleigh, UK).

\section{7. mRNA analysis}

THP-1 macrophages $\left(6 \times 106\right.$ cells $\left.\cdot \mathrm{mL}^{-1}\right)$ were incubated with TRL $\left(15 \mu \mathrm{g}\right.$ cholesterol $\left.\cdot \mathrm{mL}^{-1}\right)$ for $16 \mathrm{~h}$ and total RNA was then extracted (GenElute Mammalian Total RNA kit, Sigma-Aldrich, St. Louis, USA) with DNAase I treatment according to the manufacturer's instructions. RT and oligo(dT) were from Promega (Promega, Southampton, UK) and were used for reverse transcription. The mRNA abundance for LDLR, LRP, VLDLR, CD36, SRA2, SR B1 and the housekeeping gene glyceraldehyde 3-phosphate dehydrogenase (GAPDH) were determined by RT-PCR using SYBR green quantitative fluorescence (SYBR Green JumpStart Taq ReadyMix, sigma-Aldrich, Poole, UK) and an Opticon 2 LightCycler system (MJ Research, Waltham, Massachusetts, USA). Ct values were determined by automated threshold analysis. Data were normalized using the values obtained for GAPDH and the fold change in mRNA expression in TRL-treated as compared to control macrophages was determined by the method of Pfaffl (2001).

\subsection{Statistical analysis}

The results were expressed as means \pm SEM $(n=9)$ unless otherwise stated. Data analyses were performed with the GraphPad Prism ${ }^{\circledR} 5$ statistical package (GraphPad Software Inc., San Diego, CA). Statistical significance of differences were assessed using the following tests: for differences in TRL composition paired Student's t-test, for differences in mRNA expression unpaired Student's t-test and for intracellular lipid composition one-way ANOVA, followed by Tukey's multiple comparison test. Differences were considered statistically significant at $\mathrm{p}<0.05$. 
TABLE 4. Lipid class composition of triglyceride-rich lipoproteins (TRL) obtained from healthy volunteers 4 hours after the intake of meals rich in refined (ROO) or pomace (POO) olive oils

\begin{tabular}{lcc}
\hline & ROO $\left(\mathbf{m g} \cdot \mathbf{m g}^{-1}\right.$ TRL protein) & POO $\left(\mathbf{m g} \cdot \mathbf{m g}^{-1} \mathbf{T R L}_{\mathbf{~ p r o t e i n}}\right)$ \\
\hline TG & $3.28 \pm 0.60$ & $1.51 \pm 0.17^{*}$ \\
TC & $0.73 \pm 0.11$ & $0.43 \pm 0.08$ \\
CE & $0.23 \pm 0.04$ & $0.18 \pm 0.04$ \\
FC & $0.49 \pm 0.82$ & $0.25 \pm 0.04^{*}$ \\
PL & $0.34 \pm 0.06$ & $0.15 \pm 0.02^{*}$ \\
Total lipids & $5.07 \pm 1.60$ & $2.09 \pm 0.26^{*}$ \\
Apo B48 $\left(\mu \mathrm{g} \cdot \mathrm{mg}^{-1}\right.$ TRL protein) & $0.004 \pm 0.001$ & $0.003 \pm 0.001$ \\
Apo B100 $\left(\mu \mathrm{g} \cdot \mathrm{mg}^{-1}\right.$ TRL protein) & $0.070 \pm 0.010$ & $0.066 \pm 0.004$ \\
TG/apo B48 & $929.43 \pm 108.82$ & $360.83 \pm 54.91^{*}$ \\
TG/apo B100 & $41.72 \pm 7.64$ & $17.77 \pm 0.34^{*}$ \\
\hline
\end{tabular}

${ }^{\mathrm{a}} \mathrm{TG}$, triglycerides; TC, total cholesterol; CE, cholesterol esters; FC, free cholesterol; PL, phospholipids; Apo B: apolipoprotein B; TG/apo B: triglyceride/apo B ratio. Data are expressed as means \pm SEM, $n=9$. ${ }^{*} \mathrm{p}<0.05$, vs ROO.

\section{RESULTS}

\subsection{Lipid class composition of postprandial TRL}

Table 4 shows the lipid class composition of postprandial TRL $4 \mathrm{~h}$ after the intake of the experimental meals. TG, FC and PL and total lipid concentrations were significantly lower in TRL after consumption of POO. No significant differences were observed in apo B48 and apo B100 concentrations in TRL after the intake of both dietary oils, but the lower TG content in TRL formed after POO ingestion led to particles with significantly lower TG/apo B48 and TG/ apo B100 ratios.

\subsection{Intracellular lipid composition in THP-1 macrophages}

THP-1 macrophages were incubated with postprandial TRL in order to evaluate the influence of the modifications in their composition on the cellular uptake and intracellular lipid accumulation. Microphotographs of THP-1 cells showing intracellular lipids can be found in Figure 1 and the results in Figure 2. The intracellular concentration of both FC and CE tended to be higher when macrophages were incubated with TRL obtained after the intake of ROO but differences were not significant. In macrophages incubated with POOTRL intracellular accumulation of CE and FC was similar to that seen in control cells (absence of TRL). However, a 5 fold increase in TG intracellular accumulation was found when THP-1 macrophages were treated with TRL obtained after the intake of either ROO- or POO-TRL compared to the control cells (ROO-TRL, $\mathrm{p}<0.01$; POO-TRL, $\mathrm{p}<0.05$ ), and there was no significant difference between the two oils.

\subsection{Macrophage receptors gene expression}

The influence of postprandial TRL obtained at $4 \mathrm{~h}$ after the intake of the experimental meals containing ROO or POO on the mRNA expression of membrane receptors known to be involved in lipoprotein uptake by macrophages is shown in Figure 3.

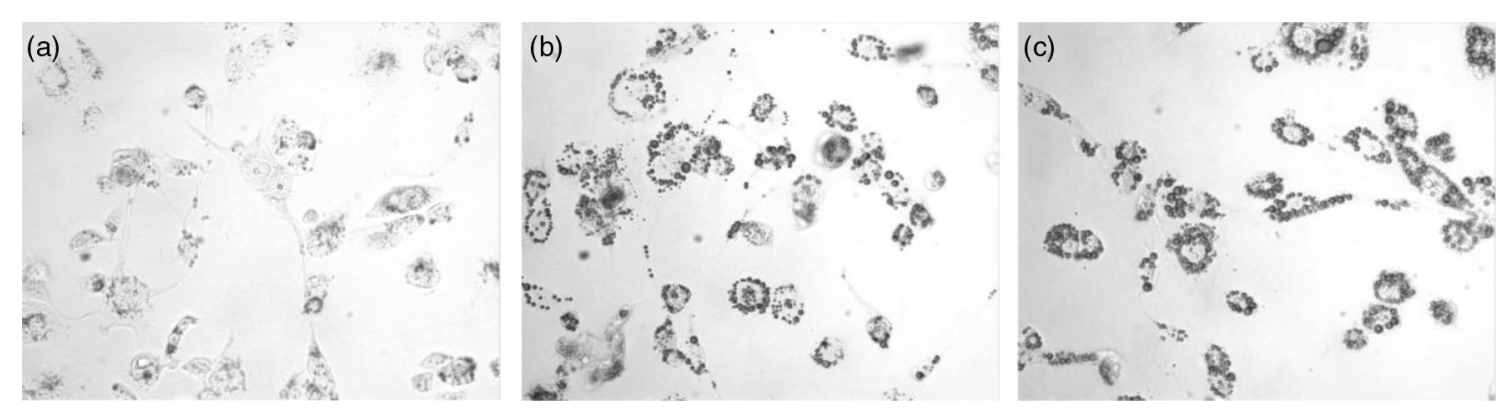

FIGURE 1. Microphotographs of THP-1 macrophages incubated for $24 \mathrm{~h}$ in the presence or absence (control, a) of TRL ( $15 \mu \mathrm{g}$ total cholesterol $\cdot \mathrm{mL}^{-1}$ ) isolated $4 \mathrm{~h}$ after the consumption of meals containing ROO (b) or POO (c) and stained with Oil Red O for visualizing lipid accumulation. Typical images from nine experiments are shown. 
(a)

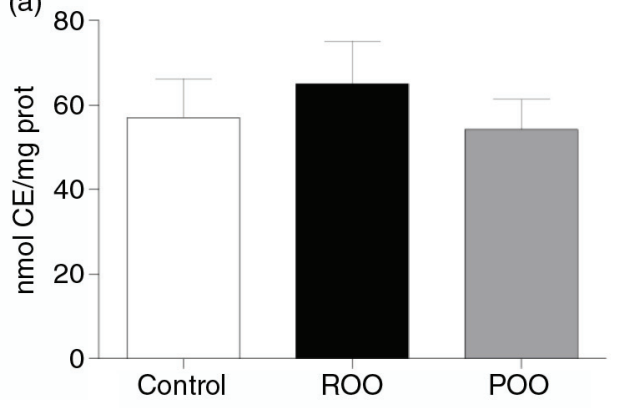

(c)

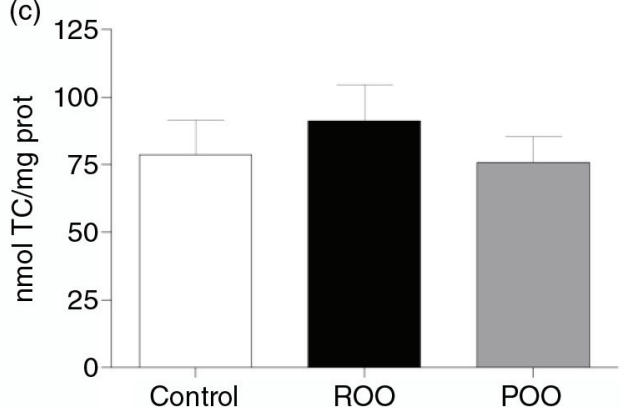

(b)

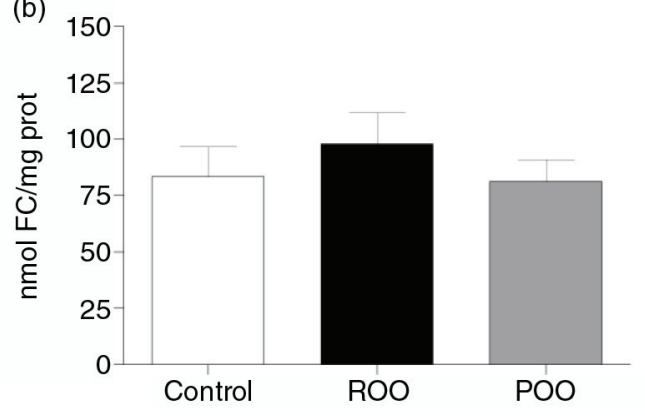

(d)

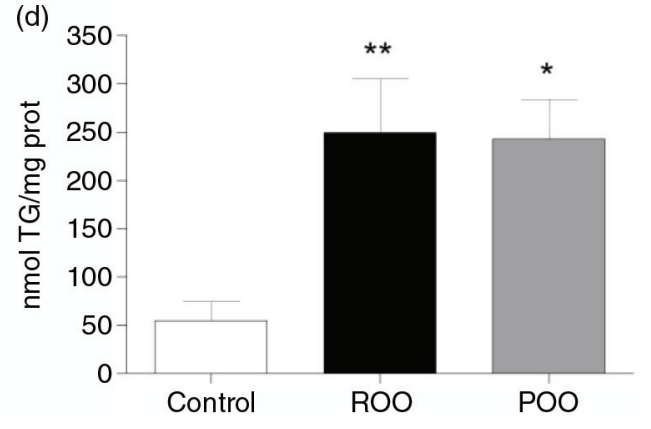

FIGURE 2. Intracellular lipid accumulation in macrophages incubated 24 hours in the absence of (control, white bar) or with TRL $\left(15 \mu \mathrm{g}\right.$ total cholesterol $\left.\cdot \mathrm{mL}^{-1}\right)$ obtained at $4 \mathrm{~h}$ after the consumption of meals containing ROO (black bar) or POO (grey bar). a: Cholesteryl esters CE; b: Free cholesterol, FC; c: Total Cholesterol, TC; d: Triglycerides, TG. Statistical significance of differences between the effects of both experimental oils compared with the Control was evaluated by one-way ANOVA followed by Tukey's multiple comparison test. ${ }^{*} \mathrm{p}<0.05,{ }^{* *} \mathrm{p}<0.01$, vs. Control. Data are expressed as means $\pm \mathrm{SD}, \mathrm{n}=9$.

The relative abundance of mRNA transcripts for the LDLR was reduced by about 50\% after incubation with TRL obtained after the ingestion of either oil. mRNA levels for LRP were less affected after incubation with TRL, although there was a slight tendency towards inhibition of the expression with TRL after the intake of POO. In contrast to LDLR and LRP, for which differences between TRL from the two oils were not significant, the increase in mRNA levels for the VLDLR caused by TRL after the intake of POO-TRL particles was significantly higher than that observed with ROO-TRL.

Unlike apo E-dependent receptors, the amounts of mRNA for scavenger receptors in the macrophages were increased in almost all cases by TRL particles obtained after the ingestion of ROO and POO. In the case of CD36, the relative abundance of mRNA transcripts was increased by up to $80 \%$ after incubation with ROO-TRL, and the effect induced by TRL obtained after POO intake was similar. The particles isolated after the ROO meal induced an increase in the mRNA expression for SR-A2 and SR-B1 genes, while those obtained after POO also showed raised levels of mRNA for SR-A2 to a lesser extent, but had little effect on the expression of mRNA for SR-B1. However, in both cases, the mRNA expression levels for SR-A2 and SR-B1 were not significantly different between ROO- and POO-TRL.

\section{DISCUSSION}

The unsaponifiable content of POO can affect the size and composition of human postprandial TRL, which might have an influence on lipoprotein atherogenicity (Cabello-Moruno et al., 2007; CabelloMoruno et al., 2014). The present study was designed to test the hypothesis that TRL particles obtained after the intake of POO, with a high unsaponifiable content, may influence foam cell formation in macrophages.

Human TRL were collected from healthy donors $4 \mathrm{~h}$ after the intake of meals rich in POO or ROO because we had observed previously that at that time point the effect on intracellular lipid accumulation after TRL uptake was at its maximum in THP-1 cells (Cabello-Moruno et al., 2014). We now show that POO as compared to ROO, significantly decreased the content of TG, FC and PL in TRL. In earlier studies, we had reported that the unsaponifiable fraction of olive oil does not exert changes in postprandial serum TG concentrations but can affect the TRL lipid composition, with 

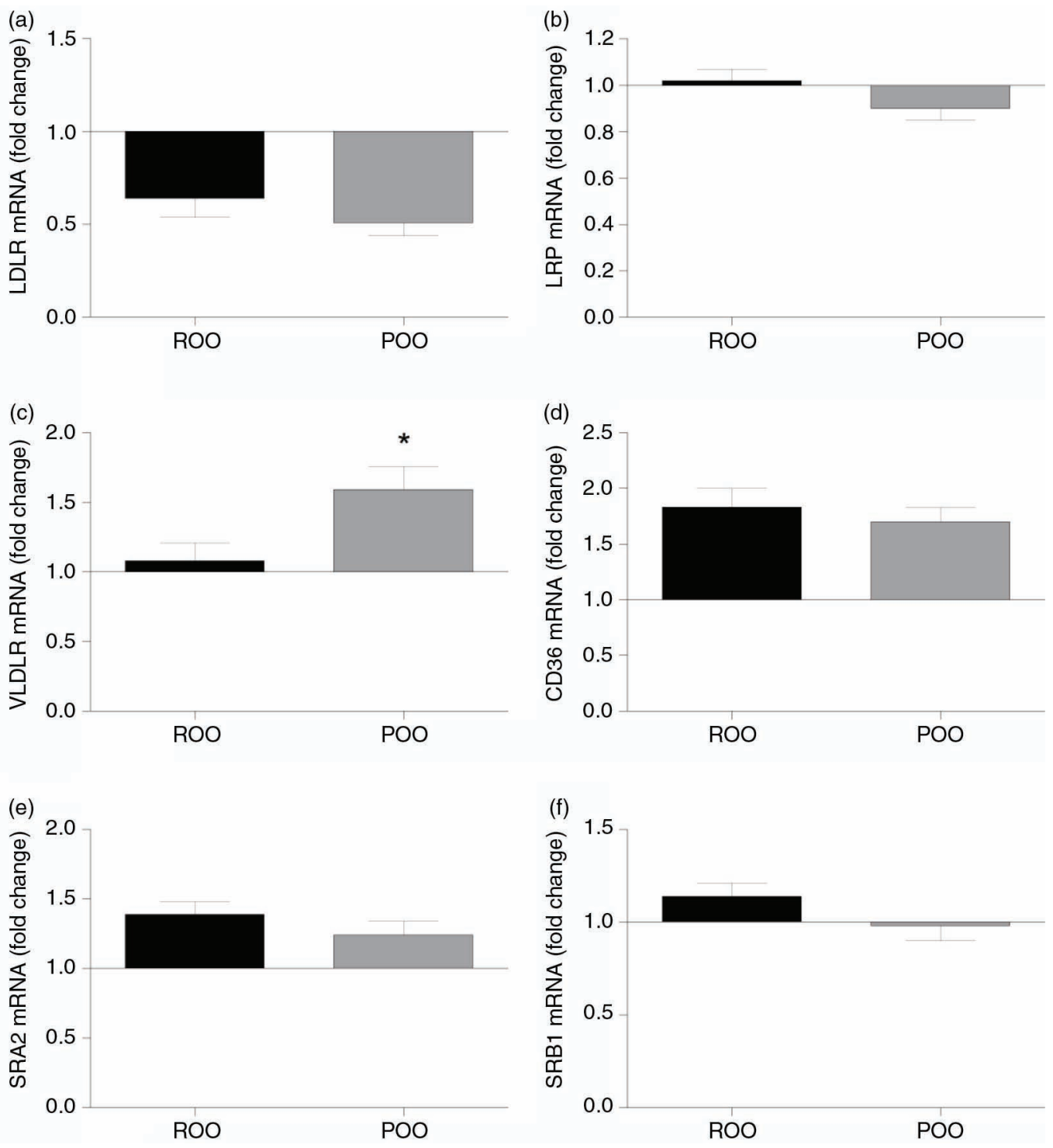

FIGURE 3. Relative abundance of mRNA expression of membrane receptors in macrophages incubated with TRL ( $15 \mu \mathrm{g}$ total cholesterol $\cdot \mathrm{mL}^{-1}$ ) obtained at $4 \mathrm{~h}$ after the intake of a meal containing refined olive oil (ROO, black bar) or pomace olive oil (POO, grey bar). a: LDLr (low-density lipoprotein receptor); b: LRP ( LDLr-related protein); c: VLDLr (VLDL receptor); d: CD36 (Scavenger receptor CD36); e: SRA2 (Scavenger receptor class A type 2); f: SRB1 (Scavenger receptor class B type 1). Data are expressed as means \pm SEM, $n=9 .{ }^{*} p<0.05$, ${ }^{* *} \mathrm{p}<0.01$, vs ROO.

important consequences for lipid uptake in different cell types (Cabello-Moruno et al., 2007; Perona et al., 2008). In the present work, the intake of either ROO or POO did not lead to significant differences in TRL apo B48 and apoB100 concentrations, suggesting that the number of both apo B48-containing particles (CM) and apo B100-containing particles (VLDL) was similar after the intake of both dietary oils. As a consequence of the modifications in the TG content but not in apo B48 and apo B100, the TG/apo B48 and TG/apo B100 ratios were significantly lower in TRL particles obtained after the POO meal. This ratio is believed to be an indicator of particle size, and it has been previously reported that TRL particles with differences in size and composition can modulate TRL clearance postprandially, which may affect TG incorporation into the tissues (Elsegood et al., 2001). The current findings suggest, therefore, that POO intake leads to smaller TRL, containing less TG molecules per particle, which could interfere with lipid incorporation into macrophages both via LPL hydrolysis and the receptor-mediated pathways (Palmer et al., 2005).

Postprandial TRL particle size may be modified by the fatty acid composition of dietary oils, with TRL obtained from MUFA-rich oils tending to be 
larger, compared to those derived from those rich in SFA, n-6 PUFA and n-3 PUFA (Jackson et al., 2002; Perez-Martinez et al., 2011). In a previous study, we showed that the unsaponifiable fraction of POO induced the release of larger TRL particles that were more rapidly hydrolyzed to their corresponding remnant particles (Cabello-Moruno et al., 2007), which was subsequently associated with a preference for the most apolar TG molecular species by LPL (Cabello-Moruno et al., 2014).

Palmer et al. (2005), demonstrated that the highest TG uptake by macrophages takes place when cells were incubated with TRL obtained at the time point at which the particle size is intermediate $(\mathrm{Sf}$ $60-400)$, ie, not as large as nascent particles ( $\mathrm{Sf}>400)$ and not as small as small-VLDL particles (Sf 20-60). The current study indicates that although POO-TRL were estimated from the TG/apoB ratio to be smaller than ROO-TRL, the two types of particles caused a similar level of intracellular lipid accumulation in macrophages, although both types of particles caused a strikingly similar increase in TG levels.

Modifications of the fatty acid composition of chylomicrons have been shown to affect their induction of lipid accumulation in macrophages (Napolitano et al., 2003). However, very little is known about the effect of olive oil minor components. Actually, to the best of our knowledge, and despite their lipophilic nature, the presence of unsaponifiable components of olive oil in postprandial TRL has not been demonstrated. Therefore, most of the biological effects of the components of the unsaponifiable fraction of olive oil have been tested in vitro and not considering their presence within postprandial TRL. Although we did not measure the content of each component of this fraction in TRL, the effects observed should be ascribed to their presence since that was the main difference between ROO and POO, as no difference was observed in the fatty acid composition of the oils.

Nevertheless, a number of authors have explored the effects of these minor components in in vitro studies. In agreement with the current results, we had found that the unsaponifiable fraction of VOO did not affect lipid accumulation in rat hepatocytes after incubation with human TRL (Perona et al., 2008). Squalene, a main component of the unsaponifiable fraction of olive oil, does not prevent monocyte migration and activation into macrophages, but it has been shown to inhibit oxidated-LDL uptake by macrophages, probably by reducing the CD36 expression (Granados-Principal et al., 2012). In combination with oleic acid, the incubation of $\beta$-sitosterol induced TG accumulation in 3T3-L1 adipocytes (Awad et al., 2000). However, Vejux et al. (2012) did not find accumulation of polar lipids in human monocytic U937 cells after incubation with phytosterols. There are very scarce data on tocopherols, but Wallert et al. (2014) demonstrated that long-chain metabolites of $\alpha$-tocopherol occurring in human serum can inhibit macrophage foam cell formation from THP-1 macrophages when treated with oxidated-LDL. These authors sugegsted that these compounds might be considered as new class of regulatory metabolites. The greatest difference between POO composition and ROO is the concentration of the aliphatic alcohol fraction (waxes) (Table 3). Policosanol, a mixture of aliphatic alcohols containing mainly octacosanol, has been demonstrated to reduce lipofundin-induced foam cell formation in rabbits and rats and to prevent the development of foam cells in carrageenan-induced granulomas in rats (Noa et al., 1996). Unfortunately, the mechanisms of these effects remain obscure and it is not presently known whether or not they are related to lower lipid accumulation in cells involved in atherogenesis, such as macrophages or smooth muscle cells.

The ingestion of POO or ROO led to TRL that were capable of reducing the expression of LDLr and inducing that of CD36 and SR-A2 to similar extents, with little effect on LRP and SR-B1. The inhibition of the LDLr expression can be explained by massive intracellular lipid accumulation, and the induction of SR-A2 and CD36 was associated with a greater TG uptake in a previous (Cabello-Moruno et al., 2014). Nonetheless, significant differences between POO-TRL and ROO-TRL were observed for the VLDLr, a member of the LDLr family that mediates the uptake of TRL by peripheral tissues (Takahashi et al., 2004). Re-introduction of VLDLr in VLDLr-KO mice significantly increases atherosclerotic lesion development, indicating that the VLDLr expressed in macrophages is a pro-atherogenic factor (Eck et al., 2005). Since VLDLr expression is downregulated by the activation of the peroxisome proliferator-activated receptor- $\alpha$ (PPAR $\alpha)$, it has been suggested that PPAR $\alpha$ agonists might help to reduce TRL uptake in macrophages (Dushkin et al., 2007).

To the best of our knowledge, there is no evidence for a direct effect of the unsaponifiable fraction of olive oil on PPAR $\alpha$ or VLDLr expression. Nevertheless, an association cannot be discarded, since Cardeno et al. (2013) reported that the unsaponifiable fraction of olive oil induced apoptosis in HT-29 human colon adenocarcinoma cells through PPAR $\gamma$ and NFKB signaling pathways. There have also been no previous studies concerning the effect of isolated components of this unsaponifiable fraction on VLDLr expression, and very little regarding PPARs. However, Plat et al. (2009) evaluated the effects of plant stanol ester consumption on PPAR $\alpha$ mRNA expression in isolated peripheral mononuclear blood cells and found no changes.

\section{CONCLUSIONS}

To summarize, the results presented here show that POO intake leads to smaller postprandial TRL compared to ROO, which is likely be related to the 
unsaponifiable content in the oil. Upon the incubation of macrophages with TRL particles, an increase in the TG content of the cells was observed but there was no difference between TRL obtained after POO or ROO intake. The two types of particles also had similar effects on the expression of mRNA for most of the receptors studied, however, the expression of the VLDLr was significantly higher in POO- than in ROO-TRL treated cells. Notwithstanding these results suggest that the VLDLr pathway might not be a main mechanism for TRL uptake in macrophages, we cannot exclude an indirect role of VLDLr via enhancement of TG hydrolysis by LPL. Indeed, Goudriaan et al. (2004) suggested that apart from its chaperone function in increasing LPL mRNA expression, VLDLr might participate in CM catabolism through the bridging of particles to the endothelial surface, thereby facilitating the LPL-particle interaction. Whether the unsaponifiable fraction of POO affects LPL expression or the interaction of VLDLr and LPL will need to be further studied.

\section{ACKNOWLEDGMENTS}

The study was registered as a clinical trial in Clinical Trials. gov with number NCT01518803. This work was supported by funds from the Spanish Ministry of Economy and Competitiveness (AGL2011-23810). The authors declare that they have no conflict of interest.

\section{REFERENCES}

Abia R, Pacheco YM, Perona JS, Montero E, Muriana FJ, RuizGutiérrez V. 2001. The metabolic availability of dietary triacylglycerols from two high oleic oils during the postprandial period does not depend on the amount of oleic acid ingested by healthy men. J. Nutr. 131, 59-65.

Awad AB, Begdache LA, Fink CS. 2000. Effect of sterols and fatty acids on growth and triglyceride accumulation in 3T3-L1 cells. J. Nutr. Biochem. 11, 153-158. http://dx.doi. org/10.1016/S0955-2863(99)00087-X.

Cabello-Moruno R, Perona JS, Osada J, Garcia M, Ruiz-Gutierrez V. 2007. Modifications in postprandial triglyceride-rich lipoprotein composition and size after the intake of pomace olive oil. J. Am. Coll. Nutr. 26, 24-31. http://dx.doi.org/10 $.1080 / 07315724.2007 .10719582$.

Cabello-Moruno, R, Sinausia, L, Botham, KM, Montero, E, Avella, M, Perona JS. 2014. Postprandial phase time influences uptake of triacylglycerol from postprandial triacylglycerol-rich lipoproteins in THP-1 macrophages. Br. J. Nutr. 23, 1-9.

Cárdeno A, Sánchez-Hidalgo M, Cortes-Delgado A, Alarcón de la Lastra C. 2013. Mechanisms involved in the antiproliferative and proapoptotic effects of unsaponifiable fraction of extra virgin olive oil on HT-29 cancer cells. Nutr. Cancer 65, 908-918. http://dx.doi.org/10.1080/01635581. 2013.806674

Chapman MJ, Ginsberg HN, Amarenco P, Andreotti F, Borén J, Catapano AL, Descamps OS, Fisher E, Kovanen PT, Kuivenhoven JA, Lesnik P, Masana L, Nordestgaard BG, Ray KK, Reiner Z, Taskinen MR, Tokgözoglu L, Tybjærg-Hansen A, Watts GF; European Atherosclerosis Society Consensus Panel. 2011. Triglyceride-rich lipoproteins and high-density lipoprotein cholesterol in patients at high risk of cardiovascular disease: evidence and guidance for management.
Eur. Heart J. 32, 1345-1361. http://dx.doi.org/10.1093/ eurheartj/ehr112.

Dushkin MI, Khoshchenko OM, Posokhova EN, Schvarts Ysh. 2007. Agonists of PPAR-alpha, PPAR-gamma, and RXR inhibit the formation of foam cells from macrophages in mice with inflammation. Bull Exp. Biol. Med. 144, 713-716. http://dx.doi.org/10.1007/s10517-007-0413-3.

Eck MV, Oost J, Goudriaan JR, Hoekstra M, Hildebrand RB, Bos IS, van Dijk KW, Van Berkel TJ. 2005. Role of the macrophage very-low-density lipoprotein receptor in atherosclerotic lesion development. Atherosclerosis 183, 230-237. http://dx.doi.org/10.1016/j.atherosclerosis.2005.03.045.

Elsegood CL, Pal S, Roach PD, Mamo JC. 2001. Binding and uptake of chylomicron remnants by primary and THP-1 human monocyte-derived macrophages: determination of binding proteins. Clin Sci (Lond). 101, 111-119. http:// dx.doi.org/10.1042/CS20010057.

Folch J, Lees M, Sloane-Stanley GH. 1957. A simple method for the isolation and purification of total lipids from animal tissues. J. Biol. Chem. 226, 497-509.

Goudriaan JR, Espirito Santo SM, Voshol PJ, Teusink B, van Dijk KW, van Vlijmen BJ, Romijn JA, Havekes LM, Rensen PC. 2004. The VLDL receptor plays a major role in chylomicron metabolism by enhancing LPL-mediated triglyceride hydrolysis. J. Lipid Res. 45, 1475-1481. http:// dx.doi.org/10.1194/jlr.M400009-JLR200.

Granados-Principal S, Quiles JL, Ramirez-Tortosa CL, OchoaHerrera J, Perez-Lopez P, Pulido-Moran M, RamirezTortosa MC. 2012. Squalene ameliorates atherosclerotic lesions through the reduction of CD36 scavenger receptor expression in macrophages. Mol. Nutr. Food Res. 56, 733-740. http://dx.doi.org/10.1002/mnfr.201100703.

Jackson KG, Poppitt SD, Minihane AM. 2012. Postprandial lipemia and cardiovascular disease risk: Interrelationships between dietary, physiological and genetic determinants. Atherosclerosis 220, 22-33.

Jackson KG, Robertson MD, Fielding BA, Frayn KN, Williams CM. 2002. Measurement of apolipoprotein B-48 in the Svedberg flotation rate (S(f)) $>400, S(f) 60-400$ and S(f) 20-60 lipoprotein fractions reveals novel findings with respect to the effects of dietary fatty acids on triacylglycerol-rich lipoproteins in postmenopausal women. Clin. Sci. (Lond) 103, 227-237.

Karpe F, Hamsten A. 1994. Determination of apolipoproteins B-48 and B-100 in triglyceride-rich lipoproteins by analytical SDS-PAGE. J. Lipid Res. 35, 1311-1317.

Laemmli UK. 1970. Cleavage of structural proteins during the assembly of the head of bacteriophage T4. Nature 227, 680-685. http://dx.doi.org/10.1038/227680a0.

Mamo JC, Wheeler JR. 1994. Chylomicrons or their remnants penetrate rabbit thoracic aorta as efficiently as do smaller macromolecules, including low-density lipoprotein, high-density lipoprotein, and albumin. Coron. Artery Dis. 5, 695-705. http://dx.doi.org/10.1097/00019501-199408000-00008.

Moore EH, Bejta F, Avella M, Suckling KE, Botham KM. 2005. Efflux of lipid from macrophages after induction of lipid accumulation by chylomicron remnants. Biochim Biophys Acta 1735, 20-29. http://dx.doi.org/10.1016/j.bbalip.2005. 04.009 .

Napolitano M, Avella M, Botham KM, Bravo E. 2003. Chylomicron remnant induction of lipid accumulation in J774 macrophages is associated with up-regulation of triacylglycerol synthesis which is not dependent on oxidation of the particles. Biochim. Biophys. Acta 1631, 255-264. http:// dx.doi.org/10.1016/S1388-1981(03)00042-8.

Noa M, de la Rosa MC, Más R. 1996. Effect of policosanol on foam-cell formation in carrageenan-induced granulomas in rats. J. Pharm. Pharmacol. 48, 306-309. http://dx.doi. org/10.1111/j.2042-7158.1996.tb05922.x.

Palmer AM, Nova E, Anil E, Jackson K, Bateman P, Wolstencroft E, Williams CM, Yaqoob P. 2005. Differential uptake of subfractions of triglyceride-rich lipoproteins by THP-1 macrophages. Atherosclerosis 180, 233-244. http://dx.doi. org/10.1016/j.atherosclerosis.2004.12.038.

Pérez-Martínez P, Ordovas JM, Garcia-Ríos A, DelgadoLista J, Delgado-Casado N, Cruz-Teno C, Camargo A, 
Yubero-Serrano EM, Rodriguez F, Perez-Jimenez F, Lopez-Miranda J. 2011. Consumption of diets with different type of fat influences triacylglycerol-rich lipoproteins particle number and size during the postprandial state. Nutr. Metab. Cardiovasc. Dis. 21, 39-45. http:// dx.doi.org/10.1016/j.numecd.2009.07.008

Perona JS, Avella M, Botham KM, Ruiz-Gutiérrez V. 2008. Differential modulation of hepatic very low-density lipoprotein secretion by triacylglycerol-rich lipoproteins derived from different oleic-acid rich dietary oils. Br. J. Nutr. 99, 29-36. http://dx.doi.org/10.1017/S0007114507793868.

Perona JS, Cabello-Moruno R, Ruiz-Gutierrez V. 2006. The role of virgin olive oil components in the modulation of endothelial function. J. Nutr. Biochem. 17, 429-445. http:// dx.doi.org/10.1016/j.jnutbio.2005.11.007.

Perona JS, Ruiz-Gutierrez V. 2004. Quantification of major lipid classes in human triacylglycerol-rich lipoproteins by high-performance liquid chromatography with evaporative light-scattering detection. J. Sep. Sci. 27, 653-659. http:// dx.doi.org/10.1002/jssc. 200301723 .

Pfaffl MW. 2001. A new mathematical model for relative quantification in real-time RT-PCR. Nucleic Acids Res. 29:e45. http://dx.doi.org/10.1093/nar/29.9.e45.
Plat J, Brufau G, Dallinga-Thie GM, Dasselaar M, Mensink RP. 2009. A plant stanol yogurt drink alone or combined with a low-dose statin lowers serum triacylglycerol and nonHDL cholesterol in metabolic syndrome patients. J. Nutr. 139, 1143-1149. http://dx.doi.org/10.3945/jn.108.103481

Takahashi S, Sakai J, Fujino T, Hattori H, Zenimaru Y, Suzuki J, Miyamori I, Yamamoto TT. 2004. The very low-density lipoprotein (VLDL) receptor: characterization and functions as a peripheral lipoprotein receptor. J. Atheroscler. Thromb. 11, 200-208. http://dx.doi.org/10.5551/jat.11.200.

Vejux A, Montange T, Martine L, Zarrouk A, Riedinger JM, Lizard G. 2012. Absence of oxysterol-like side effects in human monocytic cells treated with phytosterols and oxyphytosterols. J. Agric. Food Chem. 60, 4060-4066. http:// dx.doi.org/10.1021/jf300487r.

Wallert M, Mosig S, Rennert K, Funke H, Ristow M, Pellegrino RM, Cruciani G, Galli F, Lorkowski S, Birringer M. 2014. Long-chain metabolites of $\alpha$-tocopherol occur in human serum and inhibit macrophage foam cell formation in vitro. Free Radic Biol Med. 68, 43-51. http://dx.doi.org/10.1016/j. freeradbiomed.2013.11.009. 